答: $70 \mathrm{kVp}(27 \mathrm{keV})$ は実験エネルギーの範团がこの 程度であり平均的なすのとして選んだ. Responseの変 化の多い所で難しいところであるが，被曝線量測定上と のエネルギー領域をさける事が出来なかった。標準測定 器のプローブの径の大きさの関係から測定詔差を少なく するためにとの深さを選んだ. 特別な意味はない.

質問 (135) 岩手医大: 及川. Preannealing の不要性 はこの蓀子に限定されるのか.

答: Hawshow の素子について行った.

質問 (136) 東京: 遠藤. $\mathrm{CaSO}_{4}$ のグロー曲線の副ピー クを削除した場合，線量值は低くならないか。

答: 校正曲線で元に㞔すため，その影響はキャンセル される。

\section{治療 1 装置・器具}

座長 小沢良平（大阪府立成人病センター）

138. Tele ${ }^{60} \mathrm{CO}$ 治療に於ける検討（その二） Mix-R Compensating Filter $の$ 試作

日本大学板橋病院放射線部

○阿部勝彦・松浦 衛

伊藤英夫 ·遠藤裕二

放射線治療においては深部線量分布の平坦度の良い事 が望まれる.今回我々は照射野内体表面が平坦でない場 合の補正を目的として機質に板状水等価ゴム Mix-R を 用いた Compensating Filter 及びそれが容易に作成でき る等高線縮小トレー久装置を考案試作しその実用化につ いて検討した。 Mix-Dp，ランドファントム等を使用し フィルム法により深部線量分布図を作成した。深部にお ける補正状態を検討した結果良好に補正されている事が わかったＭix-R を使用したCompensating Filter は 作成む比較的容易な為充分日常の業務に実用が可能であ ると考える。

\section{9. 水ファントム用等線量自動記録装置の試作（第 1}

報）

神奈川県立厚木病院放射線科

斎藤美紀雄 · 大石恭範 牧田亘俊・斎藤良久

[目的]

等線量曲線は，治療計画において，必要で，現在，国 産では，等濃度自動記録装置のみで，フィルムの特性等 の補正の因子加多くあり，乙の補正に困難を伴なう。そ こで我々は㖞差の少ない等線量自動記録装置を作製し, 基礎実験を行ったので報告する.

[結果】
日本医学放射線学会, 物理部会のデータを基準とし比 較した結果, 線量率モードで, XY 軸の深部率曲線の誤 差は $1 \%$ 以内で良い結果を示し; 又等線量モードの等線 量曲線の飛程とほぼ-致し， YZ 軸の平坦度曲線からの 各\%と，YZ 軸の等線量曲線の各\%の幅も一致し 良い結 果となった. 今後, 測定時間の短縮と記録部移動を大き くし大照射野の記録を行いたい。

\section{0. 電子線照射野可変絞りの可能性について}

東北大学医学部附属病院放射線部

○高橋勇守・浅野茂夫・高野正彦

現在行われている電子線照射法は，装置附属のコーン により照射野の制約をうけている。したがって必ずしも 電子線照射療法として良好な状沿下にあるとは壱えな い. 電子線の照射野が可変となれば非常に便利であるが 現在の装置でこれを可能とするととはむずかしい. 方式 としては，コリメータにアダプタをとりつける方式と， 自由度の点汃らは多少難点が考えられるが，ヘッド下部 にアプリケータをとりつける方式とが考えられる. 今回 のアダプタ方式の䒠験では電子線の側方散乱も少なく, 実用面から期待が持てると考えられる。今後はアプリケ 一タ方式の利点とアダプタ方式の利点をとり入れ，実用 になる電子線照射野可変絞りを開発していく予定であ る.

\section{1. 放射線治療装置の線量管理}

埼玉県立がんセンター 佐藤恭二・横山 俊 関口順一・松川収作

我々は， 3 台の加速器（ベータトロン 1 台, ライナッ ク 2 台）についての長期間の測定結果より，モニタ線量 計の安定度, 経時変化等を知り, 次のような線量管理方 法を得た。

1. 定期的に行う測定結果が，ある範囲内のランダム な変動であれば，モ二タの感度補正は行わない，その之 きの許容誤差範囲は土 $1.5 \%$ とする。

2. 一定の㑯向を持った変動であれば， $11.5 \%$ 許 容誤差範囲内であっても原因を確め感度調整を行う.

3.モニタの信頼性が確認されれば，月一回の定期測 定で充分である.

4. 高湿度の期間が続く場合姣正頻度を高くする.

\section{座長集約}

この演題群は，放射線治療を開始するに当たり，事前 に測定しておくべき線量及び線量分布や，個々の治療患 者に対応した補正フィル夕等，その治療を精度よく続行 